\title{
Schedule of technical meeting
}

研究調査運営委員会情報

平成 26 年 9 月〜平成 27 年 3 月 研究会計画 : テーマと開催地一覧

\begin{tabular}{|c|c|c|c|c|}
\hline 技術委員会／委員長 & 研究会テーマ & 開催地 & 開催月 & 共催・連催・併催 \\
\hline \multirow{4}{*}{$\begin{array}{l}\text { 半導体電力変換 (SPC) } \\
\text { 佐藤 之彦(千葉大学) }\end{array}$} & パワーデバイス・パワーエレクトロニクスとその実装技術 & 茨城 & 10月 & C部門 電子デバイス技術委員会 \\
\hline & 自動車など移動体および家電用パワーエレクトロニクス & 神戸 & 12月 & $\begin{array}{l}\text { 家電·民生技術委員会 } \\
\text { 自動車技術委員会 }\end{array}$ \\
\hline & 半導体電力変換およびモータドライブ一般 & 関西 & 1月 & $\begin{array}{l}\text { モータドライブ技術委員会 } \\
\text { パワーエレクトロニクス学会 }\end{array}$ \\
\hline & 電力系統に適用される半導体電力変換技術および半導体電力変換一般 & 九州・沖縄 & 3月 & $\begin{array}{c}\text { B部門 電力技術委員会 } \\
\text { B部門 電力系統技術委員会 } \\
\end{array}$ \\
\hline \multirow{2}{*}{$\begin{array}{l}\text { 産業計測制御 (IIC) } \\
\text { 柴田 昌明 (成蹊大学) }\end{array}$} & 高度センサ応用による環境・機械・生体の計測制御技術創生 & 大阪 & 9月 & \\
\hline & International Workshop on Sensing, Actuation, and Motion Control & 名古屋 & 3月 & メカトロニクス制御技術委員会 \\
\hline \multirow{3}{*}{$\begin{array}{l}\text { メカトロニクス制御(MEC) } \\
\text { 島田 明(芝浦工業大学) }\end{array}$} & ナノスケールサーボのための制御技術 & 東京 & 9月 & \\
\hline & モーションコントロール & 神奈川 & 10月 & \\
\hline & International Workshop on Sensing, Actuation, and Motion Control & 名古屋 & 3月 & 産業計測制御技術委員会 \\
\hline \multirow{3}{*}{$\begin{array}{c}\text { モータドライブ(MD) } \\
\text { 久保田 寿夫(明治大学) }\end{array}$} & 磁性材料, モータドライブ一般, 磁気支持・リニアモータ一般 & 金沢 & 11月 & $\begin{array}{c}\text { リニアドライブ技術委員会 } \\
\text { A部門マグネテイリク技術委員会 }\end{array}$ \\
\hline & 半導体電力変換およびモータドライブ一般 & 関西 & 1月 & $\begin{array}{l}\text { 半導体電力変換技術委員会 } \\
\text { パワーエレクトロニクス学会 }\end{array}$ \\
\hline & モータドライブ一般・家電·民生技術一般 & 東京 & 3月 & 家電·民生技術委員会 \\
\hline \multirow{4}{*}{$\begin{array}{c}\text { 回転機 }(R M) \\
\text { 深見 } \\
\text { 正 }(\text { 金沢工業大学 })\end{array}$} & 電磁界数值計算技術とその応用 & 宇都宮 & 9月 & B部門 静止器技術委員会 \\
\hline & 回転機一般 & 大阪 & 10月 & \\
\hline & 直流機 & 未定 & 2月 & \\
\hline & 電磁界数值計算技術とその応用 & 宮古島 & 3月 & B部門 静止器技術委員会 \\
\hline \multirow{3}{*}{$\begin{array}{l}\text { リニアドライブ }(\mathrm{LD}) \\
\text { 北野 淳一(JR東海) }\end{array}$} & 磁性材料, モータドライブ一般, 磁気支持・リニアモータ一般 & 金沢 & 11月 & $\begin{array}{c}\text { モータドライイ゙技術委員会 } \\
\text { A部門マグネテインクク技術委員会 }\end{array}$ \\
\hline & 磁気アクチュエータ & 未定 & 12月 & A部門マグネテイツクス技術委員会 \\
\hline & 多自由度アクチュエータ & 未定 & 1月 & \\
\hline \multirow{2}{*}{$\begin{array}{c}\text { 家電・民生 }(H C A) \\
\text { 大森 英樹 (大阪工業大学) }\end{array}$} & 自動車など移動体および家電用パワーエレクトロニクス & 神戸 & 12月 & $\begin{array}{l}\text { 家電·民生技術委員会 } \\
\text { 自動車技術委員会 }\end{array}$ \\
\hline & モータドライブ一般·家電·民生技術一般 & 東京 & 3月 & モータドライブ技術委員会 \\
\hline
\end{tabular}




\begin{tabular}{|c|c|c|c|c|}
\hline 技術委員会／委員長 & 研究会テーマ & 開催地 & 開催月 & 共催•連催•併催 \\
\hline \multirow{3}{*}{$\begin{array}{c}\text { 自動車(VT) } \\
\text { 水谷 良治(トヨ夕自動車) }\end{array}$} & 鉄道一般, 移動体用エネルギーストレージ技術とその応用 & 東京 & 9月 & 交通·電気鉄道技術委員会 \\
\hline & 自動車など移動体および家電用パワーエレクトロニクス & 神戸 & 12月 & $\begin{array}{c}\text { 家電·民生技術委員会 } \\
\text { 自動車技術委員会 }\end{array}$ \\
\hline & 自動車用電源 & 名古屋 & 2月 & \\
\hline \multirow{3}{*}{$\begin{array}{l}\text { ITS (ITS) } \\
\text { 織田 利彦 } \\
\text { (道路交通情報通信 } \\
\text { システムセンター) }\end{array}$} & 交通センシング, 通信, 情報処理, 一般 & 鳥取 & 9月 & $\begin{array}{l}\text { 電子情報通信学会 } \\
\text { 情報処理学会 }\end{array}$ \\
\hline & 鉄道, ITS交通一般 & 関西 & 11月 & 交通·電気鉄道技術委員会 \\
\hline & 通信, 計測, ITS関連一般 & 京都 & 3月 & 電子情報通信学会 \\
\hline \multirow{5}{*}{$\begin{array}{l}\text { 交通・電気鉄道 (TER) } \\
\text { 渡邊 朝紀(東京工業大学) }\end{array}$} & 鉄道一般, 移動体用エネルギーストレージ技術とその応用 & 東京 & 9月 & 自動車技術委員会 \\
\hline & 運行管理·信号通信技術＋鉄道一般 & 東京 & 10月 & \\
\hline & 鉄道, ITS交通一般 & 関西 & 11月 & ITS技術委員会 \\
\hline & J-Rail & 東京 & 12月 & \\
\hline & 鉄道一般＋センサ技術 & 中部 & 3月 & E部門フイジカルセンサ技術委員会 \\
\hline \multirow{3}{*}{$\begin{array}{c}\text { ものづくり(MZK) } \\
\text { 南方 英明 (千葉工業大学) }\end{array}$} & 金属産業応用一般 & 北海道 & 9月 & \\
\hline & ものづくり関係 & 東京 & 12月 & \\
\hline & 金属産業応用一般 & 未定 & 3月 & \\
\hline \multirow{5}{*}{$\begin{array}{l}\text { 次世代産業システム(IIS) } \\
\text { 稲垣 克彦(東海大学) }\end{array}$} & Okinawa型ロボット・組み込みサスティナブルシステム & 沖縄 & 9月 & \\
\hline & G空間における複合測位技術 & 東京 & 10月 & \\
\hline & 画像応用および画像処理一般 & 長崎 & 3月 & C部門 知覚情報技術委員会 \\
\hline & Okinawa型ロボット・組み込みサスティナブルシステム & 沖縄 & 3月 & \\
\hline & 企業と教育現場における技術継承のためのIT関連技術の適用 & 大阪 & 3月 & \\
\hline \multirow{4}{*}{$\begin{array}{l}\text { スマートファシリティ(SMF) } \\
\text { 市川 紀充(工学院大学) }\end{array}$} & 建築施設監視制御工学の確立 & 東京 & 9月 & \\
\hline & 次世代ビル電気設備の安全安心技術 & 東京 & 10月 & \\
\hline & スマートシティのあるべき姿と実現に向けた課題 & 東京 & 11月 & \\
\hline & 建築施設監視制御工学の確立 & 東京 & 3月 & \\
\hline $\begin{array}{c}\text { 公共施設(PPE) } \\
\text { 横谷 守(東京都水道局) }\end{array}$ & 上下水道施設におけるICT活用に関する技術調査の報告 & 東京 & 9月 & \\
\hline
\end{tabular}

<注 $1>こ こ に$ 掲載しました予定は，平成 26 年 6 月時点の計画です。変更される場合がありますので，最新情報は，

電気学会本誌およびホームページ（http://www.iee.jp/?page_id=6818）を参照ください。

<注 2>発表申込締切は開催日の 2〜3 ケ月前, 研究会資料の原稿締め切りは 1 ヶ月前です。 